IFN Working Paper No. 1129, 2016

\title{
The Local Impacts of Agricultural Subsidies: Evidence from the Canadian Prairies
}

Ray Bollman and Shon Ferguson 


\title{
The Local Impacts of Agricultural Subsidies: Evidence from the Canadian Prairies ${ }^{1}$
}

\author{
Ray Bollman ${ }^{2}$ \\ Shon M. Ferguson ${ }^{3}$
}

June 2016

\begin{abstract}
We estimate the impact of the removal of a railway transportation subsidy on the local economies of Alberta, Saskatchewan and Manitoba, exploiting the large regional variation in these one-time freight rate increases. We find that higher freight rates - and hence lower farm gate prices - resulted in significantly lower farm revenues, farm asset values and farm numbers. Local employment in nonagricultural sectors systematically declined in areas that were hardest hit by the subsidy removal. The results suggest that the subsidy removal had detrimental spillover effects on local non-agricultural economy that are much larger than standard input-output models would predict.
\end{abstract}

JEL Classification Codes: F14, O13, Q16, Q17, Q18

Keywords: Agricultural Trade Liberalization, Export Subsidy, Market Access, Spillovers

\footnotetext{
${ }^{1}$ We thank Olga Pugatsova for her assistance with the data. A special thanks to Jason Skotheim for assistance with the freight rate data, and to Agriculture and Agri-Food Canada for providing the results of the Canadian Input-Output Model. Financial assistance from the Jan Wallander and Tom Hedelius Foundation and the Marianne and Marcus Wallenberg Foundation is gratefully acknowledged.

${ }^{2}$ Research Affiliate, Rural Development Institute, Brandon University, and Adjunct Professor, University of Saskatchewan, Canada

${ }^{3}$ Research Institute of Industrial Economics (IFN), Stockholm, Sweden
} 
Many countries continue to subsidize agriculture heavily today, and agricultural subsidies are a major roadblock to trade negotiations at the WTO and to regional trade agreement negotiations. It is thus crucial to understand how the removal of government support affects farms and rural areas. However, it is an empirical challenge to untangle the impact of subsidy reforms from other factors that affect farm and rural outcomes, such fluctuations in world grain prices and the general decline in rural population.

In this paper, we are able to overcome the identification problem by exploiting the removal of a railway transportation subsidy in Western Canada in 1995. This subsidy applied to exports of grains and oilseeds, and was deemed an export subsidy under the General Agreement on Tariffs and Trade (GATT). Crucially, the impact of the reform was location-dependent, with locations farthest from the nearest seaport experiencing the greatest increase in transportation costs upon the subsidy removal. We take advantage of this large regional variation across locations that otherwise are very similar in terms of climate, national policies, topography and pre-treatment characteristics in order to identify the causal effects of the subsidy loss on farm revenues, farm asset values, the number of farms and employment in the non-farm local economy.

Evaluating the impact of higher transportation costs in this setting is ideal for several reasons. The cost per tonne to ship grain from various inland locations in Western Canada to port position are transparent and publically available, providing us with a directly observable measure of transportation costs, which directly affect farm gate prices. Given the export-dependent nature of agricultural production in this region, prices for most agricultural commodities at inland locations are also highly transparent and driven primarily by the world price less the cost of railway transport to seaport.

Utilizing extensive Census and independent freight rate data for over 400 finely detailed spatial units across the Canadian provinces of Alberta, Saskatchewan and 
Manitoba, we present a range of new results. We find that an increase in freight rates - and hence a decrease in farm gate prices - reduced farm revenue, farm wealth and the number of farms. The results suggest that family farmers absorbed the impact of reduced farm revenue through exiting the industry and also as a reduction in their earnings. We also find that the areas where farm income, farm asset values and farm numbers decreased the most were also the areas where the non-agricultural workforce shrank the most. The results support the notion that the supply of labor is more elastic in non-agricultural sectors compared to the agriculture sector. Furthermore, the results suggest that the subsidy had indirectly supported a large number of non-agricultural jobs in rural areas of Western Canada. We find large spillover effects of agricultural exports on non-agricultural employment compared to traditional estimates of agricultural trade multipliers. This discrepancy may be caused by the fact that traditional estimates of spillovers do not imply causal effects or local impacts, and also that they ignore the additional impact of exports on farm asset values, which can spill over to the nonagricultural economy via wealth effects on consumption. Our results agree with the finding by Donaldson and Hornbeck (2016) that changes in market access via railroads can have large impacts on land values and economic growth.

This study contributes to a literature on the effect of reduced market price support, which has fallen drastically in many OECD countries, decreasing on average from 31.1 percent of production value in 1986-88 to 8.3 percent in 2011 (OECD 2013). In particular, we contribute to an extensive literature that has attempted to estimate the impact of agricultural subsidies on land values and rents (Featherstone and Baker 1988, Goodwin and Ortalo-Magné 1992, Clark et al. 1993, Veeman et al. 1993, Barnard et al. 1997, Weersink et al. 1999, Femenia et al. 2010, Kirwan 2009, Ciaian and Kancs 2012). Our work differs from these studies by focusing on the spillover effects of farm income and asset values on the non-agricultural economy. Since the reform was widely believed to be permanent, 
the loss of the subsidy translated directly into a decrease in expected income. The permanent nature of the reform thus helps us to overcome the Goodwin et al. (2003) critique that agricultural subsidies do not necessarily translate into changes in expected income when income shocks and corresponding government payments are determined by random weather or world price shocks.

This study also contributes to a literature measuring the spillover effects of agricultural productivity shocks on the local non-farm economy, such as Hornbeck (2012), who analyzes the impact of the American dust bowl on employment, farm revenues and land values at the county level. ${ }^{1}$ Similarly, Hornbeck and Keskin (2015) study the local impact of the Ogallala aquifer, and find that while the aquifer provided large gains in the agricultural sector, there was no long-run relative expansion in Ogallala counties’ non-agricultural economic activity. Although the policy reform we study is too recent to evaluate the long-run impacts, we find evidence of large spillover effects that persist up to 15 years.

Finally, this study builds on a literature that explains the pattern of regional population dynamics in Canada. Partridge et al. (2007) find that population growth in Canada has occurred primarily in or near urban centers. ${ }^{2}$ Alasia (2010) finds that Canadian communities with a higher share of employment in highgrowth sectors in 1981, a typically urban phenomenon, subsequently experienced higher population growth over the next 25 years. In contrast, communities highly reliant on traditional sectors in 1981 (typically rural) experienced significant population downsizing. Communities that were more diversified and had a higher educational attainment in 1981 also experienced higher population growth.

The paper continues with brief background of the subsidy and its subsequent removal, then a description of the conceptual framework. The empirical strategy is then explained, followed by a description of the data. The results of the regression analysis are then discussed and finally, conclusions are drawn. 


\section{Background}

We begin with a brief overview of the grain transportation subsidy and its reform, as well as a description of the grain market in Western Canada.

History of the Western Grain Transportation Act

In 1995 the Canadian Government abolished an export subsidy on railway shipments of grain from the Canadian Prairies known as the Western Grain Transportation Act (WGTA). ${ }^{3}$ This decision marked the end of one of the longestrunning agricultural subsidies in the world, first known as the Crow's Nest Pass Agreement of 1897. ${ }^{4}$ These subsidized freight rates were commonly referred to as the "Crow Rate." The removal of this transportation subsidy increased the cost of exporting grain from the prairie region of Canada by $\$ 17-\$ 34 /$ tonne, equivalent to $8 \%-17 \%$ of its value. ${ }^{5}$ These increased transportation costs translated into lower grain prices at the farm-gate.

While the subsidized grain exporters benefitted from the subsidy, livestock producers and processors were disadvantaged by the resulting higher local prices of grains, and the Crow Rate was seen as contributing to dependence on a very narrow range of crops, namely those whose export was subsidized (Klein and Kerr 1996). Removal of the transportation subsidy was expected to have significant impacts on the grains and livestock industries of the prairie region (Kulthreshra and Devine 1978).

While the repeal of the WGTA affected farmers in all locations across the prairies, there was substantial heterogeneity in the size of this impact. Prior to the reform, rail transportation rates for wheat from the prairies to seaport (Vancouver, $\mathrm{BC}$ or Thunder Bay, ON) ranged from $\$ 8$ to $\$ 14 /$ tonne, depending on location. After the reform, the rates were \$25-46/tonne, with the largest increase in freight rates being in locations that were farthest from the seaports. It is this spatial heterogeneity that allows us to identify the impact of the WGTA repeal, even in the midst of a range of other changes in the agriculture and labor markets. For 
example, world grain prices varied greatly during this time, which impacted farm revenues and asset values, but the effect of world prices were generally the same for all farmers, not differentiated by distance to seaport. ${ }^{6}$ Similarly, the Canadian economy grew and contracted several times during the period 1981-2006, but macroeconomic conditions arguably affected all rural regions in a similar way.

The timing of the WGTA removal is attributable to two main reasons. First, a recession in the early 1990's forced the Canadian federal government to implement fiscal austerity measures that initially reduced the subsidy in the 199394 and 1994-95 crop years. The pressure to balance the budget is seen as the major contributing factor to the complete removal of the subsidy in 1995. Second, the GATT deemed the WGTA to be a trade-distorting export subsidy and the Canadian government was under international pressure to reduce the subsidy. ${ }^{7}$

Farmers were partially compensated for the increase in freight rates (and the expected drop in land values that would result from the repeal of the WGTA) with a one-time payment of $\$ 1.6$ billion, and an additional \$300 million to assist producers that were most severely affected. Also, there were payments to municipalities to invest in rural roads. Land that had been used for the subsidyeligible crop in 1994 or was summerfallow was eligible. Payments were based on acreage of eligible land, a productivity factor, a distance factor and a provincial allocation factor. This compensation was equivalent to approximately two years of the annual subsidy amount and was thus not large enough to fully compensate farmers for the loss of the subsidy (Schmitz, Highmoor and Schmitz 2002). Resistance to the inadequate compensation was likely muted because the subsidy repeal had long been anticipated and because grain prices were relatively high in 1995, supporting considerable optimism about the grain-based economy.

Two other reforms occurred concurrently with the elimination of the WGTA. First, the federal government and railways began to speed up the process of abandoning prairie branch rail lines that were too inefficient to maintain. Second, 
the federal government also amended the Canada Wheat Board (CWB) Act in order to change the point of price equivalence to St. Lawrence/Vancouver, rather than Thunder Bay/Vancouver. The new pricing regime accounted for the cost to ship grain on lake freighters from Thunder Bay to the mouth of the St. Lawrence Seaway. ${ }^{8}$

Overall, the WGTA rates subsidized exports of grain to non-U.S. locations and thus the repeal of the WGTA increased the cost to ship to a seaport but did not increase the cost to ship to the U.S. In the case of grains exported by the CWB (wheat and barley for human consumption), the CWB's catchment area for exports to the U.S. was located in southern Manitoba. The WGTA repeal would have increased the U.S. catchment area, resulting in more wheat exports to the U.S. via Manitoba. ${ }^{9}$

Following the repeal of the WGTA a range of possible adaptations by farmers to the lower prices for export grains have been described (see Doan, Paddock and Dyer 2003, 2006). It was expected that some farmers would adapt to the new environment by shifting to high-value export crops, feed grain production or by pursuing economies of size in grain production. In a highly competitive market with small margins, farmers facing suddenly lower net product prices were confronted with the options of switching to higher valued crops, adopting new technologies that would reduce per unit costs or exiting the industry.

Most analysts hypothesised, at the time, that areas with a larger increase in freight rates (i.e. a larger decline in grain prices) would experience larger increases in livestock production which would dampen the impact of the reform on aggregate gross farm revenue. ${ }^{10}$

It is important to note that the 1990's were a dynamic time for the prairie economy for several reasons, such as commodity price fluctuations and agglomeration economies in or near urban areas, not just because of the repeal of the WGTA. It is thus a challenging empirical question whether the observed post- 
1995 employment patterns were attributable to the end of the WGTA or if employment would have stagnated even without the repeal of the WGTA. To the best of our knowledge such an empirical investigation has not been undertaken to date.

\section{Conceptual Framework}

The main thesis of our analysis is that removal of the export transportation subsidy for grain led to a decline in aggregate farm incomes and farm asset values, with a direct effect on average farm incomes causing a decline in the number of farms but also an indirect spillover effect on the local non-agricultural economy. The impact of reduced farm income on farm asset values is captured by the present value formula, with the key insight that any local shock to farm income is fully capitalized into the price of land in equilibrium. A reduction in farm incomes due to the removal of the transportation subsidy is expected to have a negative impact on farm income, which reduces the present value of farmland (Alston 1986, Featherstone and Baker 1988, Weersink et al. 1999). If most farmland is owned by farmers themselves (as is the case in the Canadian Prairies), it follows that a reduction in consumption spending by fewer farming families in the local non-farm economy can thus be caused by both a negative income effect and a negative wealth effect.

This study also relates to agricultural trade multipliers, which are typically measured using an input-output model with a tradable sector (agriculture) and non-tradable sectors. In these models an increase in agricultural exports results in a multiplier effect, whereby a one dollar increase in exports results in a more than one dollar increase in total economic output. The Canadian Input-Output Model (Statistics Canada 2016) found that every $\$ 1$ billion of Canadian agricultural exports in 2010 required approximately 10800 Canadian jobs throughout the economy, with $62 \%$ of those jobs accruing to the non-farm sector. ${ }^{11}$ The input- 
output approach assumes a perfectly elastic labour supply, so that changes in exports affect the number of workers but not their wage. Models of local labour markets by Rosen (1979) and Roback (1982), the price-endogenous input-output model of Haggblade et al. (1990) and a variety of Computable General Equilibrium (CGE) models have been developed to allow for more inelastic labour supply, although the multiplicative effect via indirect spillovers into nonagricultural sectors remains the same.

\section{Empirical Methodology}

As mentioned earlier, the main methodological challenge is to separate the impact of the policy reform from all of the other sources of change during the same time period. We are able to overcome this problem in the case of the WGTA reform since the effect of the freight rate increase in 1995 on a particular farm depended on its location. The effect of removing the transportation subsidy should be greater in geographic areas farther from port that experienced a larger freight rate increase in 1995 when the WGTA was repealed. We can exploit this spatial variation in the reform consequences in order to untangle the causal effect of the removal of the transportation subsidy from that of other exogenous factors that changed over time (such as world prices, the availability of new technologies, and macroeconomic conditions) independently of the policy reform. In this sense, the removal of the WGTA serves as a valuable "natural experiment" of the effect of reducing agricultural subsidies on employment in the rural economy. ${ }^{12}$

The analysis will take the form of an OLS regression using a generalized difference-in-differences methodology. We propose the following firstdifferenced specification for explaining the impact of freight costs on employment in each census consolidated subdivision (CCS): 
$\Delta Y_{i, 2001-1991}=\alpha+\beta\left(\Delta\right.$ freight $\left._{i, 2001-1991}\right)+\gamma\left(\right.$ slocaldist $\left._{i, 2001-1991}\right)+\delta_{1} Z_{i}+\varepsilon_{i}$, (1)

where $\Delta Y_{i, 2001-1991}$ is the change in the outcome variable of interest for Census Consolidated Subdivision (CCS) location $i$ between the pre-reform year 1991 and the post-reform year 2001. $\Delta$ freight $_{i, 2001-1991}$ is the change from 1991 to 2001 in freight costs per tonne of grain shipped from CCS location $i$ to port. The repeal of the WGTA caused freight rates to increase disproportionately across CCS locations and is our main variable of interest. localdist $_{i, 2001-1991}$ is the change in average distance from each CCS to its nearest delivery point, and is a proxy for the change in the cost of hauling grain by truck from the farm to the nearest grain elevator where it is loaded onto railway cars. Local trucking distance increased in most locations during the period from 1991 to 2001 due to the abandonment of branch rail lines and a reduction in the number of delivery points along surviving rail lines, making it an important control variable. $Z_{i}$ is a vector of time-constant controls such as long-term average weather, which varies across CCS locations.

It is important to emphasize that the first-differencing process subsumes the CCS fixed effects, which capture all time-constant factors that may influence the outcome variables. Adding long-run weather controls after the first-differencing process controls for the possibility that underlying climatic conditions affect the quality of life for inhabitants or farmers' ability to adapt to higher transportation costs by adopting new technologies or changing their production. For example, Ferguson and Olfert (2016) show that long-run weather is likely to affect the return to technology adoption or production changes, and this mechanism may influence farm revenues and land prices. ${ }^{13}$ We include July average temperatures and annual precipitation as controls because they reflect the availability of moisture, which can affect farm revenues. Specifically, moisture availability and growing season temperatures affect the types of crops that can be grown in a CCS 
which constrains adjustment alternatives. We also include average January temperature because they are inherently related to distance from the west coast, which is correlated with our freight rate measure. For example, cold winters may affect the economics of cattle production, since cattle require more feed in cold temperatures. As a consequence, farms further from seaports with colder winters may not be able to adapt to higher grain transportation costs by feeding grain to livestock, which can affect farm revenues and hence rural employment. In order to ensure that our freight rate coefficient is not spuriously driven by underlying climatic characteristics it is vital to control for climate averages in the analysis.

The constant term $\alpha$ in this first-differenced specification picks up the change in the dependent variable that is due to factors that affect all locations identically, such as world grain prices and macroeconomic conditions.

We estimate equation (1) using gross farm revenue, the value of land and buildings, the number of farms, and non-agricultural employment, all aggregated at the CCS level, as dependent variables. The main coefficient of interest is $\beta$, with the null hypothesis that $\beta=0$. We expect a greater increase in freight rates to be associated with a greater decline in farm revenues and asset values, which will cause a subsequent decline in the number of farms and local non-agricultural employment.

The size of the coefficient $\beta$ can be interpreted is a measure of inter-regional differences in the impact of the reform. In other words, the coefficient $\beta$ indicates how a \$1/tonne rise in freight rates between 1991 and 2001 impacts the change (relative to the change in the average CCS) in the dependent variables at the CCS level. For example, consider two locations on the Prairies where freight rates rise between 1991 and 2001 by \$15/tonne and \$25/tonne respectively. Given that the increase in freight rates for these two locations differed by $\$ 10 /$ tonne, the coefficient $\beta$ allows us to predict that a $10 * \beta$ difference in the dependent variable between these two locations can be attributed to the reform. 
It is important to emphasize that our identification strategy is able to tease out the spatially different impacts (relative to the average) of the policy change across regions but does not capture the total impact of the policy. All locations experienced an increase in freight rates as a result of the WGTA repeal, and the measurement of the total impact is confounded by other time-varying factors during the same time period.

We perform this analysis at an aggregated level, which prohibits us from exploring heterogeneity within geographic units or controlling for individual factors that affect labour market outcomes.

\section{Data and Descriptive Statistics}

One of the unique features of our data is that it combines freight rate data with data from the Census of Agriculture and the Census of Population. This section explains the data sources and how they were combined.

\section{Census of Population and Census of Agriculture}

The primary data is taken from the Canadian Census of Population, aggregated to the Census Consolidated Subdivision (CCS) level. A CCS is, typically, a statistical grouping (“consolidation”) of an incorporated town with the surrounding incorporated rural municipality (or county in Alberta). The Census of Population is undertaken every five years. We require data for several years before and after the 1995 reform in order to identify the effect of the WGTA repeal on farm and community employment outcomes. We therefore use data from the 1981, 1986, 1991, 1996, 2001 and 2006 census years in our analysis. We

use data on the "experienced workforce" in the non-agricultural sector. ${ }^{14}$ Constant 1996 CCS boundaries were used to control for changes in boundaries between years and amalgamations of CCS's over time. The CCS boundaries are illustrated in figure 1. We also use data from the Canadian Census of Agriculture to obtain 
data on the number of farms, gross farm revenues and the market value of land and buildings, which is available for the same years.

\section{Freight rates}

We combine data on farm and community outcomes from the Census of Population and the Census of Agriculture with freight rate data supplied by Freight Rate Manager, a service provided by a consortium of government, academic and farmer organizations. ${ }^{15}$ The freight rate data encompass the freight rate for wheat from at most 992 delivery locations spread across Alberta, Saskatchewan and Manitoba. ${ }^{16}$ We measure freight rates from several grid points within each CCS, using a 0.1 degree grid of the earth's surface, then take the average freight rate for all grid points within a given CCS as our measure of each CCS's freight rate. ${ }^{17}$

We measure average local trucking costs from the farm to the delivery location using the average distance measure from each grid point to the nearest delivery location. The change in distances over time reflects the effect of the branch line abandonment or other rail transport consolidation that may have happened even in the absence of the subsidy repeal. Controlling for the change in distance allows us to isolate the other effects of the change in freight rates. ${ }^{18}$

The pattern of freight rate changes between 1991 and 2001 by CCS is illustrated in figure 1. Note that while freight rates increased for all locations between 1991 and 2001, there was large variation in the size of this increase across geographic space, even within individual provinces. The largest freight increases were in Northeastern Saskatchewan, which is the most remote location in terms of distance to both the west coast and the Great Lakes.

Figure 2 illustrates the abrupt increase in freight rates in the 1995-1996 crop year, using data for Saskatoon, Saskatchewan. The figure also illustrates that primary elevator tariffs for wheat, which is the fee charged by grain companies to store and load grain onto railway cars, were generally constant over the 1986- 
2006 period. ${ }^{19}$ Figure 2 also illustrates that wheat prices fluctuated greatly during this period.

Weather, soil and distance to urban centers

The weather data include 20-year average precipitation and temperature in each CCS. Environment Canada weather data for every weather station across the prairies was matched to our CCS-level data using GIS. The weather data for a specific CCS represent the weather data available from the nearest weather station with at least 20 years of data.

Distance to the nearest urban center is distance (in kilometers) from each CCS to the nearest Census Agglomeration or Census Metropolitan Area (i.e., a center of 10,000 or more).

As a robustness check we also include soil zone data as an additional control. The soil data describes the percentage of each CCS that is brown, dark brown, black, dark gray or gray soil. The color of the soil is determined by the level of organic matter it contains, which is itself related to the vegetation and hence by long-run weather. Brown soil is found in the most arid parts of the prairies which was previously a grassland ecosystem. Black soil is found in the moister areas of the prairies, which was previously covered by long grass or deciduous trees. Gray soil is found in areas with coniferous forest. The soil data originates from the Soil Science GIS Lab at the University of Saskatchewan, which was based on the soil classification protocol from the Canada Land Inventory maps. A map of the soil zones is provided in Appendix figure A2.

A first glance at the data

As a first pass at the data we compare several characteristics between 1991 and 2001 for regions that subsequently experienced relatively large and small freight rate increases. We divide CCS's into two groups: CCS's where the change in the 
freight rate between 1991 and 2001 is above the median, and CCS's where the change in the freight rate is below the median.

Table 1 illustrates that regions experiencing a relatively large increase in freight rates also exhibited less growth in the non-agricultural workforce, a faster reduction in the number of farms, as well as less growth in gross farm revenues and farmland and farm building values. ${ }^{20}$ Since the number of acres devoted to agriculture remained fairly constant during this time, average farm size (in acres) in each CCS increased by 18\% during the 1991 to 2001 period. The trend towards fewer, larger farms over time features prominently in many developed countries, and is typically driven by the development of labour-saving farming technology, changes in farm organization and government policies (Kislev and Peterson 1982, Key and Roberts 2007, MacDonald, Korb, and Hoppe 2013, see Sumner 2014 for a review of the literature.) As noted in Table 1, the 'high' and 'low' freight-rateincrease CCS's are also unevenly distributed over provinces, and across soil zones. For example, twice as many CCS's in the brown soil zone fell into the 'smaller' freight rate increase category, while the majority of CCS's with black soil fell into the "greater freight rate increase" category. These ex ante characteristics must, of course, be controlled for when evaluating the impact of the reform.

Table 1 also illustrates that CCS's experiencing above-median increases in freight rates tended to have colder winters and warmer summers. In Table 2 the raw correlations between the independent variables indicate that CCS's experiencing greater freight rate increases tended to experience a smaller increase in local trucking distances, colder winters and warmer summers. These results emphasize how crucial it is to control for trucking distance and weather averages in the regressions, since they can affect the extent to which farmers can adapt to the loss of the subsidy. 
In Figure 3 we illustrate the changes in our outcome variables over time using a graphical approach. Panel A illustrates a divergence in gross farm revenue between regions that experienced relatively large vs. small freight rate increases. The impact does not show up in the 1996 census since the one-time compensatory payment raised farm revenues in 1995, and gross farm revenue reported on the 1996 Census of Agriculture refers to the 1995 calendar year. However, by the 2001 census one observes a clear divergence between gross farm revenues in line with expectations. The value of land and buildings, illustrated in Panel B also indicates a decline between 1996 and 2001, with a small divergence in the value of land and buildings has already beginning between 1991 and 1996. Panel C illustrates that a divergence in farm numbers occurred between 1991 and 1996, which was exactly the time that the reform was announced and implemented. Panel D illustrates that the non-agricultural workforce declined drastically in the 2001 and 2006 census years, which directly coincides with the decline in farm revenues and farm asset values shown in Panels A and B.

\section{Main Results}

The main results are summarized in tables 3 and 4 . We first estimate the impacts of the increase in freight rates between 1991 and 2001 on the growth in gross farm revenues and farm asset values. We then estimate the impact on the number of farms the non-agricultural workforce. We cluster all regressions at the Census Division level, which are larger geographical units composed of several CCS's. This provides us with up to 58 clusters, depending on the specification.

\section{Gross farm revenues and farm asset values}

The impact of a higher freight rates on the growth of gross farm revenues and the value of farm land and buildings is reported in columns (1)-(4) and (5)-(8) of table

3 respectively. The explanatory variable of main interest is $\Delta$ freight $_{i, 2001-1991}$. In column (1) we find that a greater increase in freight rates led to a statistically 
significant decrease in gross farm revenues. We add controls for the change in trucking costs (proxied by the change in local trucking distance) and weather averages in columns (2) and (3) respectively. Finally, we control for distance to the nearest urban center in column (4). We repeat the process in columns (5)-(8) when the dependent variable is the value of farm land and buildings. The point estimates for $\Delta$ freight $_{i, 2001-1991}$ are negative and statistically significant in all specifications, which agrees with the graphical results in figure 3 and the twosample t-test given in table 1 . In column (4) we find that a greater increase in freight rates had a negative impact on the change in gross farm revenues, with each one dollar per tonne increase in freight rates leading to a 1.28 percent decline in gross farm revenues. In column (8) we find that we find that higher freight rates had a negative impact on the value of farm land and buildings, with each one dollar per tonne increase in freight rates leading to a 2.97 percent decline in asset values.

The result for the localdist $_{i, 2001-1991}$ control variable are weak in table 3 , as we find a no impact on farm income or asset values once all controls are included. New technologies that allowed farmers to more easily adapt to greater local trucking distance may explain why we do not find robust impacts of the change in the local trucking distance. Farmers adapted by using larger trucks to haul their grain or outsourcing grain transportation to trucking companies. Longer local trucking distances were a consequence of high-capacity elevators replacing smaller, less efficient elevators. These high-capacity elevators captured economies of size in grain handling which were partly passed on to farmers in the form of trucking incentives (Vercammen 1996b). The efficiency gains from having fewer, larger elevators thus partially offset the detrimental effects of increased local trucking distance. 
Overall, we find that gross farm revenues and farm asset values responded negatively to the removal of the subsidy, with asset values responding most elastically.

The number of farms and the non-agricultural workforce

The impact of higher freight rates on the growth in the number of farms and the non-agricultural workforce is shown in columns (1)-(4) and (5)-(8) of table 4 respectively. The point estimate for $\Delta$ freight $_{i, 2001-1991}$ in column (4) suggest that each additional one dollar increase in freight rates resulted in a 0.85 percent decrease in the number of farms in a CCS on average. The point estimates for $\Delta$ freight $_{i, 2001-1991}$ in column (4) of tables 3 and 4 suggest that the reduction in the number of farms did not keep pace with the reduction in farm revenue, which implies that revenue per farm also declined due to the reform.

The effects of higher freight rates on the non-agricultural workforce are large. According to the point estimate in column (8) of table 4, every one dollar per tonne increase in the freight rate in a CCS led to a decrease of 2.46 percentage points in non-agricultural employment. For example, compare two locations that experienced a \$15/tonne vs. \$25/tonne freight rate increase. Since the freight rate increases at these locations differed by $\$ 10 /$ tonne, our results indicate that nonagricultural employment will be $10 * 2.46=24.6$ percentage points lower in the more severely affected location. Compared with the average growth in the nonagricultural workforce was 7.8 percent between 1991 and 2001 (See table 1), the impact of freight rates is economically significant.

The elasticity of the number of farms with respect to freight rates is 0.19 , while the elasticity of the non-agricultural workforce with respect to freight rates is 0.55. Since most of the agricultural workforce is self-employed family farmers, these results suggest that employment in agriculture was less responsive to the subsidy loss compared non-agricultural employment. 
The point estimate for $\Delta$ freight $_{i, 2001-1991}$ suggests that each one dollar increase in freight rates translates into 13 fewer jobs per CCS. ${ }^{21}$ In contrast, the Canadian agricultural trade multiplier would predict only one 1.4 fewer jobs per CCS for each one dollar increase in freight rates, assuming that each one dollar increase in freight rates reduces farm revenues by $\$ 124,000$ in the median CCS. ${ }^{22}$ Our reduced-form estimates of the multiplier are much larger than input-outputbased measures for several reasons. First, our estimation captures causal effects, whereas input-output models do not. Second, our estimate is based on local, not country-wide impacts. Finally, the local nature of our estimation strategy means that local farm asset values were also affected by the reform, which likely had additional negative spillover effects on non-agricultural employment via wealth effects on consumption.

The result for the slocaldist $_{i, 2001-1991}$ control variable are mixed in table 4, as we find an unexpected positive effect on the number of farms but no statistically significant impact on the non-agricultural workforce. The lack of an effect of local trucking distance on local non-agricultural employment makes sense given the inconclusive impact of trucking distance on farm income and farm asset values. Moreover, outsourcing grain transportation to trucking companies may have a positive impact on local non-agricultural employment, which may offset any negative impacts on local non-agricultural employment via a reduction in farm income and farm asset values.

We find that January temperatures are statistically significant and negatively related to growth in the non-agricultural workforce when we add the weather controls in column (7). Finally, we find that CCS's further from urban centers had a negative and statistically significant effect on the non-agricultural workforce in column (8). 


\section{Robustness}

We check whether our results for the non-agricultural workforce, the most novel contribution of the paper, are robust using a placebo treatment and by adding additional controls for province, soil zone and pre-reform wheat acreage, education, income and farm size. We also present our results when weighting the sample. We also discuss issues of identification and how general equilibrium effects influence our results.

\section{Placebo treatment}

Since we have data on the non-agricultural workforce as far back as 1981, we apply a pre-reform placebo treatment to check whether or not the non-agricultural workforce in the most afflicted CCS's already started to change between 1981 and 1991. We therefore regress the 1981-1991 change in the non-agricultural workforce on the 1991-2001 change in freight rates. If we find no impact then we can trust that our estimates in table 4 are not spuriously driven by pre-1991 changes in the workforce. The results of this placebo treatment are given in table 5. Reassuringly, we find no statistically significant impacts of freight rate changes between 1991 and 2001 on growth in the non-agricultural workforce between 1981 and 1991 once all controls are added in column (4).

\section{Robustness to additional controls}

One concern is that our results for the effect of freight rates are driven simply by province-specific factors. The population of Alberta, for example, grew much faster during this period compared with Saskatchewan and Manitoba, which may spuriously drive our results. We thus control for province-specific trends by including province dummy variables in all specifications. Alberta_dum and Manitoba_dum take a value of 1 if the CCS is located in Alberta or Manitoba respectively and zero otherwise; Saskatchewan is the omitted province. Since our dependent variables are first-differenced, these dummies control for heterogeneity in employment trends that vary by province or inter-provincial policy differences. 
Including province dummies means that the $\Delta$ freight $_{i, 2001-1991}$ coefficient utilizes the within-province spatial variation in freight rate increases.

In column (1) of table 6 we find that our results are robust to controlling for provincial trends, with the coefficient on $\Delta$ freight $_{i, 2001-1991}$ left almost unchanged. The coefficients on the province dummies are not statistically significant, which suggests that the impact of provincial differences were captured by the first-differencing process or by the other control variables.

As an additional robustness check we control for soil characteristics in each CCS and education levels in 1991 that may affect employment patterns. In column (2) we find that the share of brown soil is weakly negatively associated with the growth of the non-agricultural workforce. The January temperature control loses significance in column (2), which is likely caused by the fact that soil zones are inherently related to climatic conditions. In column (3) we find that the share of university-educated population in 1991 is not systematically related to growth in the non-agricultural workforce.

\section{Weighted regressions}

Another cause for concern is that the CCS's display a large degree of heterogeneity in size in terms of total population. In an effort to test the implications of heterogeneous population across CCS's we re-run the analysis weighting the employment regressions by 1991 population and the gross revenue and value of land and building regressions with their respective 1991 values. ${ }^{23}$ The results reported in the Appendix in table A1. For all four dependent variables we find that freight rates continue to have highly significant point estimates. Weighting the regressions has very little impact on the magnitude of the point estimates for $\Delta$ freight $_{i, 2001-1991}$ when the dependent variables are farm revenues, the value of farm land and buildings and the number of farms in columns (1), (2) and (3) respectively. Weighting leads to a smaller point estimate 
for $\Delta$ freight $_{i, 2001-1991}$ in column (4) when the dependent variable is the growth in non-agricultural employment.

Identification and general equilibrium effects

While reverse causality is unlikely to be a problem in the analysis, a potential concern is that a correlation between freight rate increases and our outcome variables may be driven by additional omitted geographical factors that vary with distance from the seaports. The difference-in-differences approach controls for all time-invariant differences across census units, which arguably controls for much of the underlying geographical factors. The robustness checks control for any trends in adoption that are systematically driven by province-specific factors, soil zone attributes, pre-reform farm size distributions or pre-reform educational attainment and income levels among people living in each CCS.

The subsidy removal may also have impacted employment via general equilibrium effects. The fact that some CCS's were affected more than others by the reform implies that there was scope for migration within the prairie region from more severely affected CCS's to less severely affected CCS's. Migration of this nature would inflate our estimates since internal migration would lead to higher population and employment growth in the less-affected CCS's. One way to control for this is to drop all CCS's within "predominantly urban" regions (as defined by the OECD). The regression results excluding urban CCS's is given in the Appendix in table A2, where we find that our main results are unchanged for all four outcome variables.

\section{Conclusion}

The sudden and spatially differentiated increases in freight rates experienced in Western Canada after 1995 serves as a useful natural experiment that allows us to evaluate the impact of agricultural export subsidies on local employment. Overall, we find large and statistically significant negative effects of the space-differential 
aspects of the policy reform, relative to the average change experienced by all Prairie localities, on farm income, farm asset values, the number of farms and non-agricultural employment. Farms and communities distant from a seaport were hit hardest.

The results show that the supply of labor is more elastic in non-agricultural sectors compared to the agriculture sector. Furthermore, the results suggest that the export subsidy had indirectly supported a large number of non-agricultural jobs in rural areas of Western Canada. The results suggest that the reform led to fewer farming families due, in part, to lower aggregate farm income which led to lower farm asset values and a lower the level of local employment in the nonagricultural sector in locales with a larger increase in freight rates. These results provide a valuable lesson for policymakers in other countries that are considering reforms to agricultural subsidies. Our results suggest that the removal of agricultural subsidies is felt not only by farmers themselves but also their surrounding communities. 


\section{References:}

Agriculture and Agri-Food Canada (AAFC). 2006. Summative Evaluation of the Prairie Grain Roads Program (PGRP), Final Report. Ottawa: AAFC Audit and Evaluation Team.

Alasia, A. 2010. "Population Change Across Canadian Communities: The Role of Sector Restructuring, Agglomeration, Diversification and Human Capital.” Rural and Small Town Canada Analysis Bulletin Vol. 8, No. 4 (Ottawa: Statistics Canada, Catalogue no. 21-006-XIE).

Alston, J. M. 1986. "An analysis of growth of US farmland prices, 1963-82." American Journal of Agricultural Economics 68(1): 1-9.

Autor, D., D. Dorn and G. Hanson. 2013. "The China Syndrome: Local Labor Market Effects of Import Competition in the United States," American Economic Review 103(6): 2121-68.

Barnard, C.H., Whittaker, G., Westenbarger, D. and Ahearn, M. 1997. “Evidence of Capitalization of Direct government Payments into U.S. Cropland Values”. American Journal of Agricultural Economics, 79(5):1642-1650.

Bell, M. “Maple Leaf pulls plug on hog plant.” The Western Producer, October 19, 2006.

Canadian Grain Commission. 2014. “Grain Deliveries at Prairie Points,” 1985-86, 1990-91, 1995-96, 2000-01 and 2005-06 Crop Years.

http://www.grainscanada.gc.ca/statistics-statistiques/gdpp-lgpcp/gdppm-mlgpcpeng.htm. Accessed August 8, 2014.

Canadian Transportation Agency. 2012. Statistics on the Revenue Cap for Western Grain. Available at: https://www.otc-cta.gc.ca/eng/statistics-railwayrevenue-cap-western-grain Accessed July 8, 2014. 
Ciaian, P. and A. Kancs. 2012. “The Capitalization of Area Payments into Farmland Rents: Micro Evidence from the New EU Member States,” Canadian Journal of Agricultural Economics 60(4):517-540.

Clark, J., K. Klein and S. Thompson. 1993. “Are Subsidies Capitalized into Land Values? Some Time Series Evidence from Saskatchewan,” Canadian Journal of Agricultural Economics 41(2):155-168.

Dakers, S. and J.D. Fréchette. 2001. The Grain Industry in Canada. Government of Canada, Parliamentary Research Branch, PRB 98-2E.

Doan, D., B. Paddock and J. Dyer. 2003. “Grain Transportation Policy and Transformation in Western Canadian Agriculture.” Proceedings of International Agricultural Policy Reform and Adjustment Project (IAPRAP) Workshop, Paper \#15748, October 23-25, 2003, Imperial College London: Wye Campus

Doan, D., B. Paddock and J. Dyer. 2006. “The Reform of Grain Transportation Policy and Transformation in Western Canadian Agriculture,” in Blanford, D. and B. Hill (eds.) Policy Reform and Adjustment in the Agricultural Sectors of Developed Countries, pp. 163-174. Oxfordshire, UK: CABI Pub.

Donaldson, D. and R. Hornbeck. 2016. "Railroads and American Economic Growth. A ‘Market Access’ Approach.” Quarterly Journal of Economics (forthcoming).

Featherstone, A. M., \& Baker, T. G. 1988. "Effects of Reduced Price and Income Supports on Farmland Rent and Value.” North Central Journal of Agricultural Economics, 10(2):177-189.

Femenia, F., A. Gohin and A. Carpentier. 2010. “The Decoupling of Farm Programs: Revisiting the Wealth Effect,” American Journal of Agricultural Economics 92 (3):836-848. 
Ferguson, S. M., and M. R. Olfert. 2016. "Competitive Pressure and Technology Adoption: Evidence from a Policy Reform in Western Canada." American Journal of Agricultural Economics 98(2):422-446.

Friesen, A. 2002. “Western Grain Transportation Reform and Agricultural Diversification.” Compiled by Grain Policy Division, Markets and Trade Team, Agriculture and Agri-Food Canada, Winnipeg, MB.

Fulton, M., K. Baylis, H. Brooks and R. Gray. 1998. "The Impact of Deregulation on the Export Basis in the Canadian Grain Handling and Transportation System.” Working paper, Department of Agricultural Economics, University of Saskatchewan.

Goodwin, B. and F. Ortalo-Magné. 1992. “The Capitalization of Wheat Subsidies into Agricultural Land Values” Canadian Journal of Agricultural Economics 40(1):37-54.

Goodwin, B., A. Mishra and F. Ortalo-Magné. 2003. "What’s Wrong with Our Models of Agricultural Land Values? American Journal of Agricultural Economics 85(3):744-752.

Haggblade, S., Hammer, J. and Hazell, P. 1991.” Modeling agricultural growth multipliers,” American Journal of Agricultural Economics 73(2):361-374.

Hornbeck, R. 2012. "The Enduring Impact of the American Dust Bowl: Shortand Long-Run Adjustments to Environmental Catastrophe,” American Economic Review 102(4):1477-1507.

Hornbeck, R. and P. Keskin. 2015. “Does Agriculture Generate Local Economic Spillovers? Short-Run and Long-Run Evidence from the Ogallala Aquifer,” American Economic Journal: Applied Economics 7(2): 192-213. 
Key, N.D. and Roberts, M.J. 2007. Commodity payments, farm business survival, and farm size growth (No. 51). U.S. Department of Agriculture, Economic Research Service.

Kirwan, B. 2009. “The Incidence of U.S. Agricultural Subsidies on Farmland Rental Rates.” Journal of Political Economy 117(1):138-164.

Kislev, Y., and W. Peterson. 1982. “Prices, Technology, and Farm Size.” Journal of Political Economy 90(3):578-595.

Klein, K.K., S.N. Kulshreshtha, G. Stennes, G. Fox, W.A. Kerr and J. Corman. 1994. "Transportation Issues in Canadian Agriculture II: Analysis of the Western Grain Transportation and Feed Freight Assistance Acts.” Canadian Journal of Regional Science 17(1):45-70.

Klein, K.K. and W.A. Kerr. 1996. “The Crow Rate Issue: A Retrospective on the Contribution of the Agricultural Economics Profession in Canada.” Canadian Journal of Agricultural Economics 44(1):1-18.

Kraft, D.F. and J. Doiron. 2000. "Post Crow Influence on Prairie Feed Grain Prices.” Paper presented September 29, 2000 at Western Nutrition Conference, Winnipeg.

Kulthreshra, S.N. and D.G. Devine. 1978. "Historical Perspective and Propositions on the Crowsnest Pass Freight Rate Agreement.” Canadian Journal of Agricultural Economics 26(2):72-83.

MacDonald, J.M., Korb, P. and Hoppe, R.A. 2013. Farm size and the organization of US crop farming. US Department of Agriculture, Economic Research Service. OECD. 2013. OECD: Estimates of support to agriculture (USD). In Agricultural Policy Monitoring and Evaluation 2013, OECD Publishing. DOI: 10.1787/agr_pol-2013-table18-en. 
Partridge, M. D., M. R. Olfert and A. Alasia. 2007. "Canadian Cities as Regional Engines of Growth: Agglomeration and Amenities.” Canadian Journal of Economics, Vol. 40, No. 1, pp. 39-68.

Partridge, Mark D., Dan S. Rickman, Kamar Ali and M. Rose Olfert. 2008. “Lost in Space: Population Dynamics in the American Hinterlands and Small Cities.” Journal of Economic Geography 8(6):727-57.

Ramankutty, N., A.T. Evan, C. Monfreda, and J.A. Foley. 2008. "Farming the Planet: 1. Geographic Distribution of Global Agricultural Lands in the Year 2000.” Global Biogeochemical Cycles 22(1). DOI: 10.1029/2007GB002952. Ross, J. 2006. “Grain Elevators.” In Canadian Encyclopaedia. Available at http://www.thecanadianencyclopedia.ca/en/article/grain-elevators/. Accessed May 9, 2014.

Roback, J.1982. "Wages, Rents, and the Quality of Life," Journal of Political Economy 90(6):1257-78.

Rosen, S. 1979. “Wage-based indexes of urban quality of life.” In Peter N. Miezkowski and Mahlon R. Straszheim (eds.) Current Issues in Urban Economics. Baltimore, MD: Johns Hopkins University Press, 74-104. Saskatchewan Agriculture, Food and Rural Revitalization (SAFRR). 2003. Agricultural Statistics 2002. Regina, SK: SAFRR, Policy Branch.

Schmitz, T.G., T. Highmoor, and A. Schmitz. 2002. "Termination of the WGTA:

An Examination of Factor Market Distortions, Input Subsidies and Compensation.” Canadian Journal of Agricultural Economics 50(3):333-347.

Statistics Canada. 2016. Canadian Input-Output Model 2010. Impact of agriculture on exports. Ottawa:Macroeconomic Accounts Branch, Industry Accounts Division. 
Sumner, D. A. 2014. American Farms Keep Growing: Size, Productivity, and Policy. Journal of Economic Perspectives 28(1), 147-166.

United States Department of Agriculture (USDA) Economic Research Service. 2012. "Effects of Trade on the U.S. Economy: 2014 Data Overview. Washington, DC: USDA.

Veeman, M., X. Dong, and T. Veeman. 1993. "Price Behavior of Canadian Farmland." Canadian Journal of Agricultural Economics 41(2):197-208.

Vercammen, J. 1996a. “An Overview of Changes in Western Grain Transportation Policy.” Canadian Journal of Agricultural Economics 44(4):397402.

Vercammen, J. 1996b. “Module C-1: The Economics of Rail Incentive Rates.” In J. Vercammen, M. Fulton and R. Gray, eds. The Economics of Western Grain Transportation and Handling. 1996 Van Vliet Publication Series. Saskatoon: University of Saskatchewan.

Weersink, A., Clark, S., Turvey, C. G., and Sarker, R. 1999. “The Effect of Agricultural Policy on Farmland Values,” Land Economics 75(3):425-439. Wilson, W. W. and D. Johnson. 1995. "Understanding the Canada/United States Grains Dispute: Background and Description." Agriculture and Food Policy Systems Information Workshop: Understanding Canada/United States Grain Disputes, (1995), pp. 113-132. Rio Rico, Arizona, USA: Farm Foundation. Wilson, W. W. and B. Dahl. 2000. "Logistical Strategies and Risks in Canadian Grain Marketing.” Canadian Journal of Agricultural Economics 48:141-160. Wilson, W. W. and B. Dahl. 2011. "Grain Pricing and Transportation: Dynamics and Changes in Markets.” Agribusiness 27(4):420-434. 


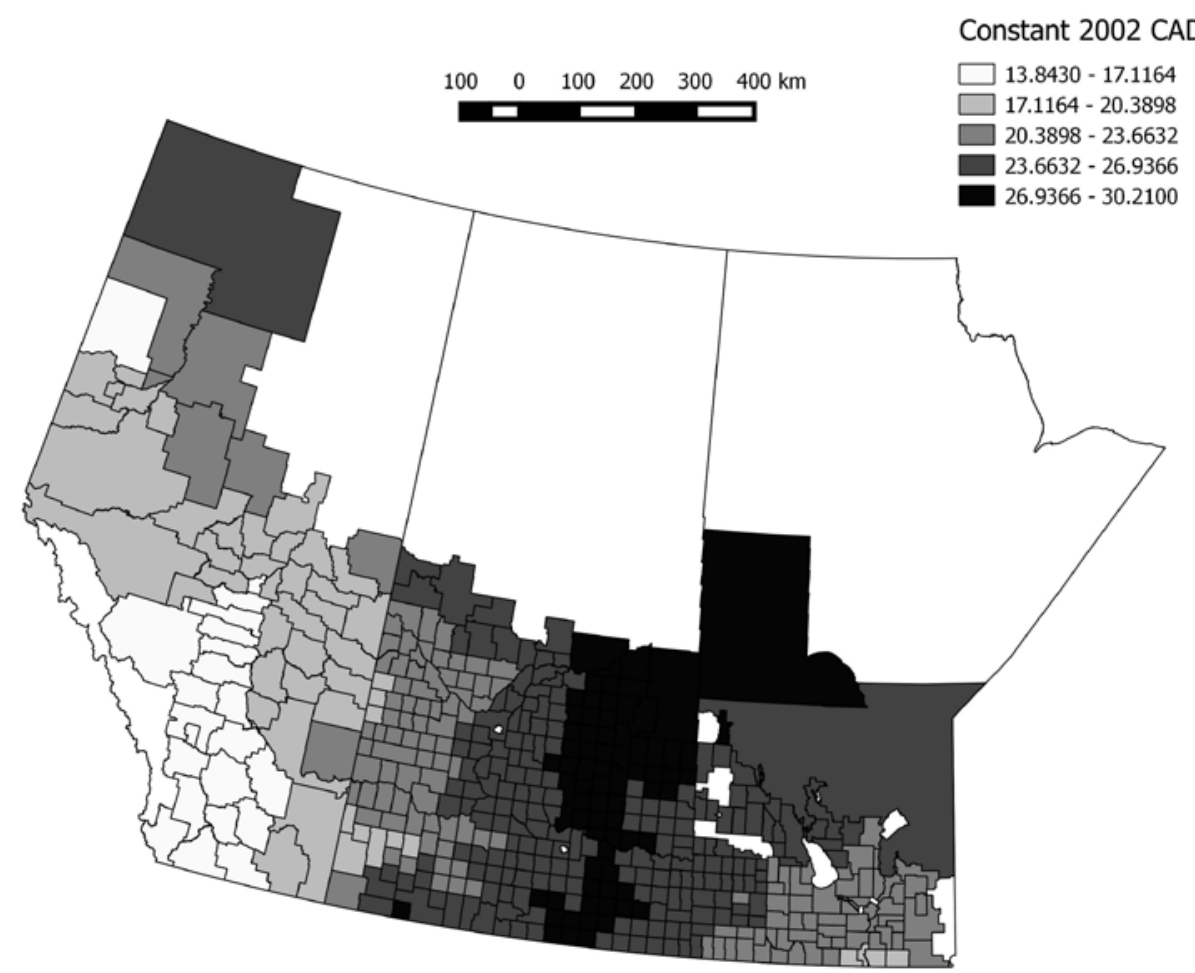

Figure 1. Freight rate changes between 1991 and 2001 and 1996 Census Consolidated Subdivision boundaries for the prairie provinces

Note: Areas with no fill indicate CCS’s without Census data or CCS's where data was amalgamated with neighboring CCS's for confidentiality reasons.

Source: Statistics Canada and Freight Rate Manager. 


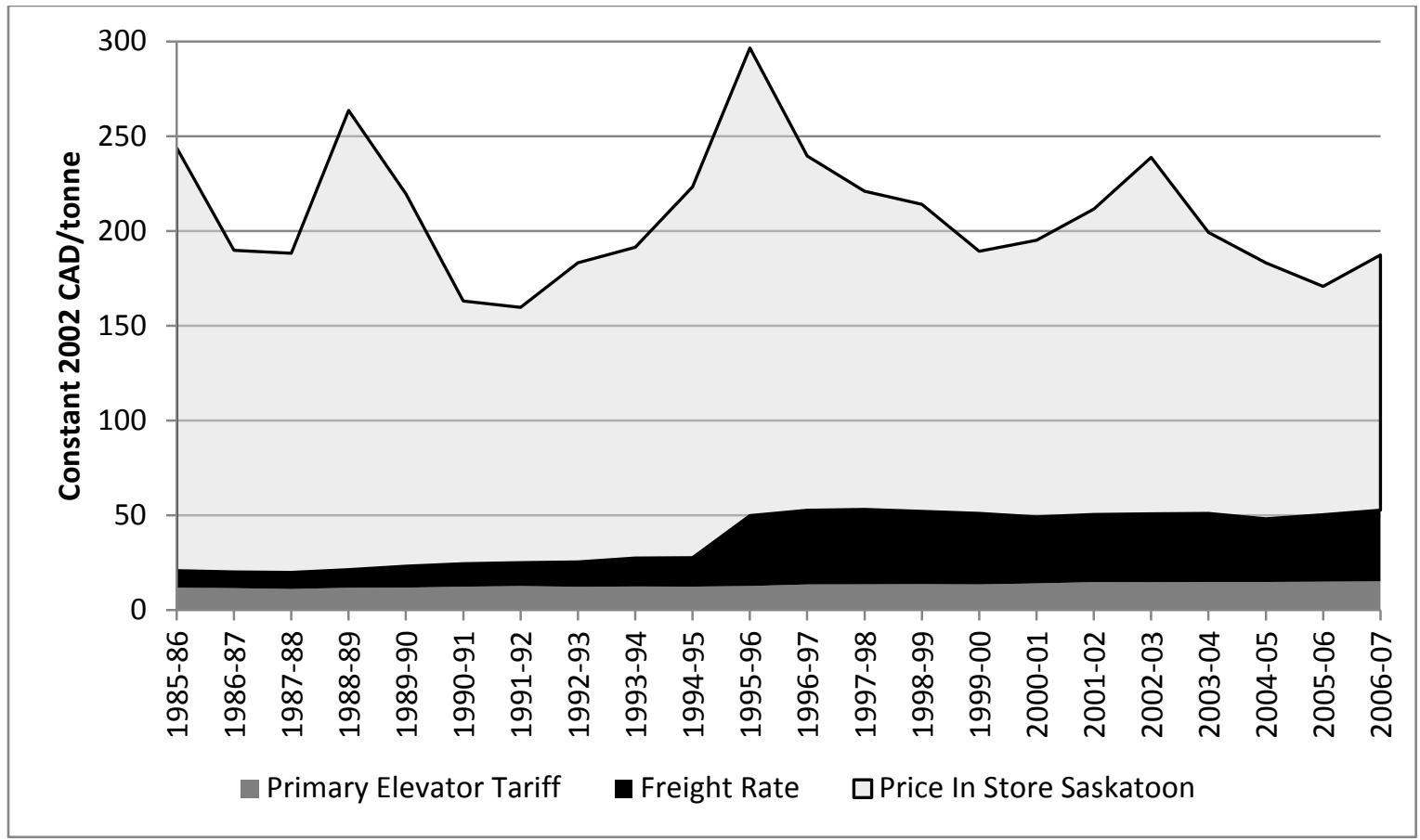

Figure 2. Primary elevator tariff, freight rate and price in store, Saskatoon SK, \#1 Canada Western Red Spring Wheat, $12.5 \%$ protein

Source: Saskatchewan Agriculture and Food. 


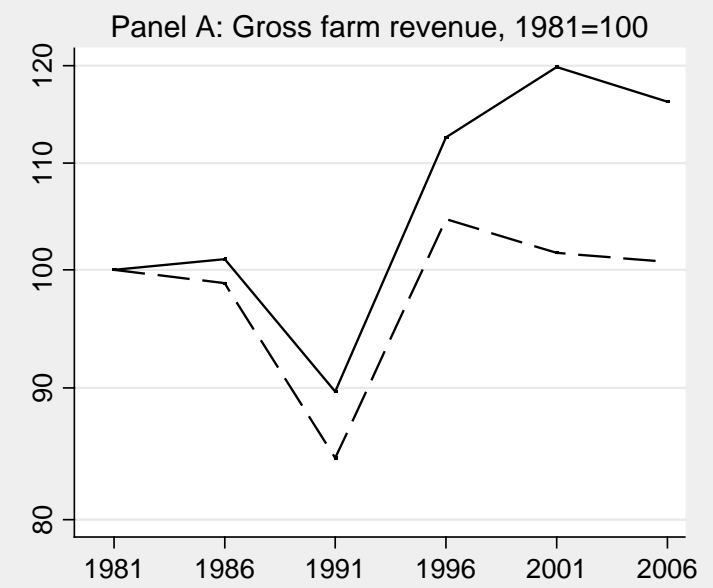

Panel B: Value of farm land \& bldgs., 1981=100

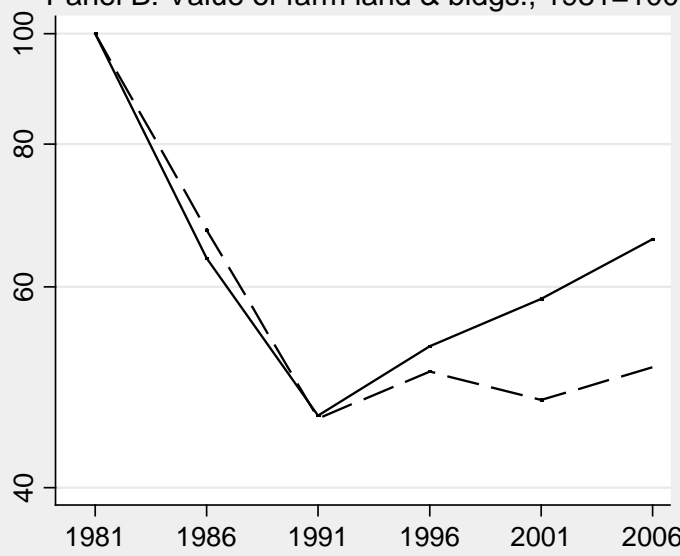

Panel C: Total Number of Farms, 1981=100

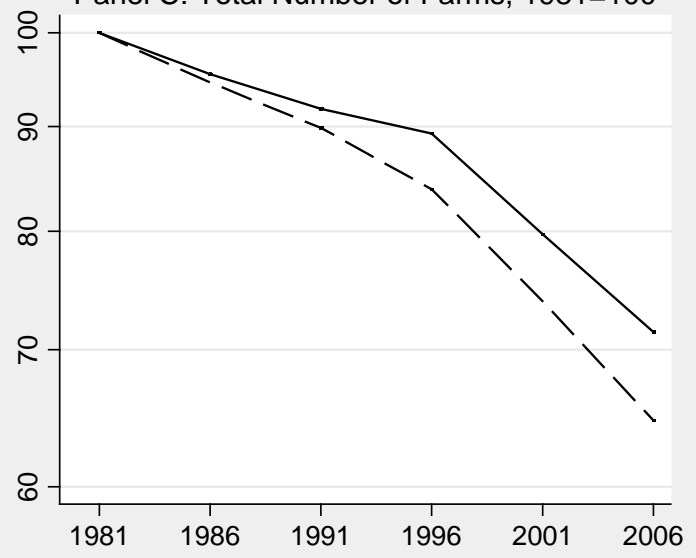

Panel D: Non-Ag Workforce, 1981=100

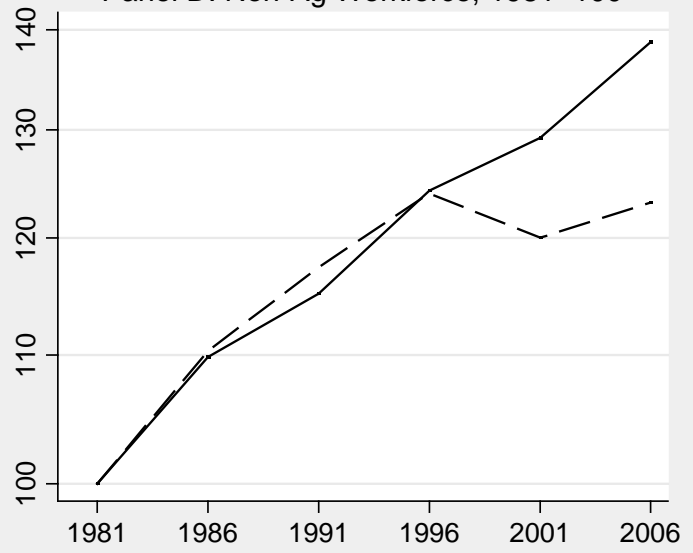

Below-median freight increase

Above-median freight increase

Figure 3. Trends in outcome variables by census year for CCS's with freight rate changes above vs. below the median 
Table 1. Descriptive Statistics

\begin{tabular}{|c|c|c|c|c|}
\hline Freight rate increase, relative to median, 2001-1991: & $\begin{array}{c}\text { All } \\
\text { CCS's }\end{array}$ & $\begin{array}{l}\text { Below } \\
\text { median }\end{array}$ & $\begin{array}{l}\text { Above } \\
\text { median }\end{array}$ & $\begin{array}{c}\text { Group } \\
\text { Difference }\end{array}$ \\
\hline \multicolumn{5}{|l|}{ Percentage Change in Dependent Variables, 2001-1991: } \\
\hline Non-agricultural workforce (NonAG_Wkforce $\left.e_{i, t}\right)$ & 7.8 & 12.3 & 3.4 & $-8.9 * * *$ \\
\hline Number of census farms (numfarms $i_{i, t}$ ) & -15.0 & -12.3 & -17.6 & $-5.3^{* * *}$ \\
\hline Gross farm revenues excluding forest products (revenue ${ }_{i, t}$ ) & 27.1 & 32.5 & 21.8 & $-10.7 * * *$ \\
\hline Value of farm land and buildings ( valuel $_{i, t}$ ) & 15.7 & 27.4 & 4.1 & $-23.2 * * *$ \\
\hline \multicolumn{5}{|l|}{ Independent Variable Means: } \\
\hline Freight rate change, 2001-1991, wheat, $\$ /$ tonne ( 4 freight $_{i, 2001-1991}$ ) & 22.44 & 19.78 & 25.10 & $5.32 * * *$ \\
\hline Local trucking distance change, 2001-1991, km (_localdist $t_{i, 2001-1991)}$ & 5.7 & 6.0 & 5.5 & -0.5 \\
\hline Average January temperature, degrees Celcius $\left(j a n \_t e m p_{i}\right)$ & -15.8 & -14.9 & -16.7 & $-1.8^{* * *}$ \\
\hline Average July temperature, degrees Celcius (july_temp $p_{i}$ ) & 18.0 & 17.7 & 18.2 & $0.5^{* * *}$ \\
\hline Average annual precipitation, mm ( precip $\left._{i}\right)$ & 441 & 443 & 439 & -4 \\
\hline Distance to nearest urban area $(\mathrm{km})\left(\right.$ dist_urban $\left._{i}\right)$ & 79 & 71 & 87 & $16^{* * *}$ \\
\hline \multicolumn{5}{|l|}{ Number of CCS's by category: } \\
\hline Alberta & 68 & 66 & 2 & \\
\hline Saskatchewan & 299 & 99 & 200 & \\
\hline Manitoba & 117 & 77 & 40 & \\
\hline Brown Soil Zone & 74 & 53 & 21 & \\
\hline Dark Brown Soil Zone & 102 & 35 & 67 & \\
\hline Black Soil Zone & 189 & 94 & 95 & \\
\hline Dark Gray Soil Zone & 34 & 17 & 17 & \\
\hline Gray Soil Zone & 38 & 19 & 19 & \\
\hline
\end{tabular}

Notes: A CCS is considered belonging to a particular soil zone if that soil type covers at least $50 \%$ of its area. ${ }^{* * *} \mathrm{p}<0.01,{ }^{* *} \mathrm{p}<0.05,{ }^{*} \mathrm{p}<0.1$ 
Table 2: Raw correlations between independent variables

\begin{tabular}{|c|c|c|c|c|c|}
\hline & $\Delta$ freight $_{i, 2001-1991}$ & Slocaldist $_{i, 2001-1991}$ & jan_temp $_{i}$ & july_temp $_{i}$ & precip $_{i}$ \\
\hline Dlocaldist ${ }_{i, 2001-1991}$ & $-0.16^{*}$ & & & & \\
\hline jan_temp $p_{i}$ & $-0.57 *$ & $0.24 *$ & & & \\
\hline july_temp $_{i}$ & $0.40 *$ & $-0.31^{*}$ & $-0.13^{*}$ & & \\
\hline precip $_{i}$ & -0.07 & 0.03 & $-0.29 *$ & -0.08 & \\
\hline dist_urban ${ }_{i}$ & $0.17 *$ & $0.22 *$ & $-0.15^{*}$ & $-0.15^{*}$ & 0.05 \\
\hline
\end{tabular}

Notes: * indicates pairwise correlation coefficients significant at the $5 \%$ level or better. 
Table 3. The impact of higher freight rates on gross farm revenues and the value of farm land and buildings

\begin{tabular}{|c|c|c|c|c|c|c|c|c|}
\hline \multirow{3}{*}{ Dep. Variable: } & \multicolumn{8}{|c|}{10 year difference-in-differences (2001-1991) } \\
\hline & \multicolumn{4}{|c|}{$\Delta \ln \left(\right.$ revenue $\left._{i 2001-1991}\right)$} & \multicolumn{4}{|c|}{$\Delta \ln \left(\right.$ valuelb $\left._{i 2001-1991}\right)$} \\
\hline & $(1)$ & (2) & (3) & (4) & (5) & (6) & (7) & (8) \\
\hline$\Delta$ freight $_{i, 2001-1991}$ & $\begin{array}{c}-0.0182^{* * *} \\
(0.00561)\end{array}$ & $\begin{array}{c}-0.0176^{* * *} \\
(0.00570)\end{array}$ & $\begin{array}{l}-0.0132 * * \\
(0.00646)\end{array}$ & $\begin{array}{l}-0.0128^{*} \\
(0.00639)\end{array}$ & $\begin{array}{c}-0.0373 * * * \\
(0.00503)\end{array}$ & $\begin{array}{c}-0.0366^{* * *} \\
(0.00504)\end{array}$ & $\begin{array}{c}-0.0292^{* * *} \\
(0.00573)\end{array}$ & $\begin{array}{c}-0.0297 * * * \\
(0.00563)\end{array}$ \\
\hline Alocaldist ${ }_{i, 2001-1991}$ & & $\begin{array}{c}0.00168 \\
(0.00121)\end{array}$ & $\begin{array}{c}0.00149 \\
(0.00125)\end{array}$ & $\begin{array}{c}0.00168 \\
(0.00116)\end{array}$ & & $\begin{array}{l}0.00200 * \\
(0.00104)\end{array}$ & $\begin{array}{l}0.000941 \\
(0.00108)\end{array}$ & $\begin{array}{l}0.000704 \\
(0.00110)\end{array}$ \\
\hline precip $_{i}$ & & & $\begin{array}{c}9.70 \mathrm{e}-05 \\
(0.000242)\end{array}$ & $\begin{array}{c}0.000101 \\
(0.000241)\end{array}$ & & & $\begin{array}{c}0.000392^{* *} \\
(0.000167)\end{array}$ & $\begin{array}{c}0.000387 * * \\
(0.000172)\end{array}$ \\
\hline jan_temp $p_{i}$ & & & $\begin{array}{c}0.0143 * \\
(0.00763)\end{array}$ & $\begin{array}{c}0.0143 * \\
(0.00765)\end{array}$ & & & $\begin{array}{l}0.0130^{* *} \\
(0.00542)\end{array}$ & $\begin{array}{l}0.0131^{* *} \\
(0.00551)\end{array}$ \\
\hline july_temp $_{i}$ & & & $\begin{array}{c}0.0128 \\
(0.0125)\end{array}$ & $\begin{array}{c}0.0123 \\
(0.0126)\end{array}$ & & & $\begin{array}{l}-0.0144 \\
(0.0107)\end{array}$ & $\begin{array}{l}-0.0137 \\
(0.0107)\end{array}$ \\
\hline dist_urban $_{i}$ & & & & $\begin{array}{l}-0.000153 \\
(0.000323)\end{array}$ & & & & $\begin{array}{c}0.000199 \\
(0.000297)\end{array}$ \\
\hline Constant & $\begin{array}{c}0.611^{* * *} \\
(0.126)\end{array}$ & $\begin{array}{c}0.589 * * * \\
(0.131)\end{array}$ & $\begin{array}{l}0.442 * \\
(0.252)\end{array}$ & $\begin{array}{l}0.451^{*} \\
(0.255)\end{array}$ & $\begin{array}{c}0.961 * * * \\
(0.111)\end{array}$ & $\begin{array}{c}0.934 * * * \\
(0.114)\end{array}$ & $\begin{array}{c}1.064^{* * *} \\
(0.190)\end{array}$ & $\begin{array}{c}1.053^{* * *} \\
(0.193)\end{array}$ \\
\hline Observations & 473 & 473 & 473 & 473 & 473 & 473 & 473 & 473 \\
\hline$R$-squared & 0.061 & 0.064 & 0.082 & 0.083 & 0.341 & 0.347 & 0.367 & 0.368 \\
\hline
\end{tabular}

Notes: Robust standard errors in parentheses, clustered at the Census Division level. ${ }^{* * *} \mathrm{p}<0.01,{ }^{* *} \mathrm{p}<0.05,{ }^{*} \mathrm{p}<0.1$ 
Table 4. The impact of higher freight rates on the number of farms and the non-agricultural workforce

\begin{tabular}{|c|c|c|c|c|c|c|c|c|}
\hline \multirow{3}{*}{ Dep. Variable: } & \multicolumn{8}{|c|}{10 year difference-in-differences (2001-1991) } \\
\hline & \multicolumn{4}{|c|}{$\Delta \ln \left(\right.$ numfarms $\left._{i, 2001-1991}\right)$} & \multicolumn{4}{|c|}{$\Delta \ln \left(\right.$NNonAG Wkforce $_{i, 2001-1991)}$} \\
\hline & $(1)$ & $(2)$ & (3) & (4) & (5) & (6) & (7) & $(8)$ \\
\hline$\Delta$ freight $_{i, 2001-1991}$ & $\begin{array}{c}-0.0147 * * * \\
(0.00338)\end{array}$ & $\begin{array}{c}-0.0138^{* * *} \\
(0.00348)\end{array}$ & $\begin{array}{c}-0.00932^{* * *} \\
(0.00267)\end{array}$ & $\begin{array}{c}-0.00845^{* * *} \\
(0.00261)\end{array}$ & $\begin{array}{c}-0.0165^{* * *} \\
(0.00428)\end{array}$ & $\begin{array}{c}-0.0179 * * * \\
(0.00427)\end{array}$ & $\begin{array}{c}-0.0272^{* * *} \\
(0.00666)\end{array}$ & $\begin{array}{c}-0.0246 * * * \\
(0.00670)\end{array}$ \\
\hline Alocaldist $_{i, 2001-1991}$ & & $\begin{array}{c}0.00281^{* * *} \\
(0.000933)\end{array}$ & $\begin{array}{l}0.00191 * \\
(0.00102)\end{array}$ & $\begin{array}{c}0.00227^{* *} \\
(0.00101)\end{array}$ & & $\begin{array}{c}-0.00360^{* *} \\
(0.00172)\end{array}$ & $\begin{array}{l}-0.00244 \\
(0.00147)\end{array}$ & $\begin{array}{l}-0.00152 \\
(0.00139)\end{array}$ \\
\hline precip $_{i}$ & & & $\begin{array}{c}-1.93 e-05 \\
(9.61 e-05)\end{array}$ & $\begin{array}{l}-1.06 e-05 \\
(8.93 e-05)\end{array}$ & & & $\begin{array}{c}0.000171 \\
(0.000164)\end{array}$ & $\begin{array}{c}0.000185 \\
(0.000159)\end{array}$ \\
\hline jan_temp $p_{i}$ & & & $\begin{array}{c}0.00459 \\
(0.00389)\end{array}$ & $\begin{array}{c}0.00451 \\
(0.00375)\end{array}$ & & & $\begin{array}{c}-0.0216 * * * \\
(0.00791)\end{array}$ & $\begin{array}{c}-0.0227^{* * *} \\
(0.00725)\end{array}$ \\
\hline july_temp $_{i}$ & & & $\begin{array}{c}-0.0212 * * * \\
(0.00665)\end{array}$ & $\begin{array}{c}-0.0224 * * * \\
(0.00666)\end{array}$ & & & $\begin{array}{l}0.00294 \\
(0.0113)\end{array}$ & $\begin{array}{l}-0.00251 \\
(0.0123)\end{array}$ \\
\hline dist_urban $_{i}$ & & & & $\begin{array}{l}-0.000309 \\
(0.000214)\end{array}$ & & & & $\begin{array}{c}-0.000863^{* *} \\
(0.000341)\end{array}$ \\
\hline Constant & $\begin{array}{c}0.157 * \\
(0.0783)\end{array}$ & $\begin{array}{c}0.120 \\
(0.0826)\end{array}$ & $\begin{array}{c}0.487 * * * \\
(0.157)\end{array}$ & $\begin{array}{c}0.508^{* * *} \\
(0.154)\end{array}$ & $\begin{array}{c}0.419 * * * \\
(0.0883)\end{array}$ & $\begin{array}{c}0.471^{* * *} \\
(0.0908)\end{array}$ & $\begin{array}{c}0.204 \\
(0.220)\end{array}$ & $\begin{array}{c}0.283 \\
(0.222)\end{array}$ \\
\hline Observations & 474 & 474 & 474 & 474 & 484 & 484 & 484 & 484 \\
\hline$R$-squared & 0.124 & 0.152 & 0.177 & 0.184 & 0.052 & 0.068 & 0.113 & 0.133 \\
\hline
\end{tabular}

Notes: Robust standard errors in parentheses, clustered at the Census Division level. ${ }^{* * *} \mathrm{p}<0.01,{ }^{* *} \mathrm{p}<0.05,{ }^{*} \mathrm{p}<0.1$ 
Table 5. Non-agricultural workforce robustness, pre-reform placebo treatment

\begin{tabular}{|c|c|c|c|c|}
\hline & \multicolumn{4}{|c|}{$\begin{array}{c}10 \text { year first-difference }(1991-1981) \\
\text { Dependent variable: } \Delta \ln \left(\text { NonAG_Wkforce }{ }_{i, 1991-1981}\right)\end{array}$} \\
\hline & $(1)$ & $(2)$ & (3) & (4) \\
\hline$\Delta$ freight $_{i, 2001-1991}$ & $\begin{array}{c}-0.00620 * * \\
(0.00285)\end{array}$ & $\begin{array}{c}-0.00636 * * \\
(0.00297)\end{array}$ & $\begin{array}{l}-0.00288 \\
(0.00473)\end{array}$ & $\begin{array}{c}-0.000206 \\
(0.00482)\end{array}$ \\
\hline Llocaldist $_{i, 2001-1991}$ & & $\begin{array}{l}-0.000411 \\
(0.00111)\end{array}$ & $\begin{array}{r}-0.000998 \\
(0.00115)\end{array}$ & $\begin{array}{l}-1.70 \mathrm{e}-05 \\
(0.00110)\end{array}$ \\
\hline precip $_{i}$ & & & $\begin{array}{c}0.000203 \\
(0.000196)\end{array}$ & $\begin{array}{c}0.000226 \\
(0.000180)\end{array}$ \\
\hline jan_temp $p_{i}$ & & & $\begin{array}{c}0.00475 \\
(0.00564)\end{array}$ & $\begin{array}{c}0.00397 \\
(0.00580)\end{array}$ \\
\hline july_temp $_{i}$ & & & $\begin{array}{l}-0.00838 \\
(0.00915)\end{array}$ & $\begin{array}{c}-0.0130 \\
(0.00883)\end{array}$ \\
\hline dist_urban $_{i}$ & & & & $\begin{array}{c}-0.000889 * * * \\
(0.000285)\end{array}$ \\
\hline Constant & $\begin{array}{l}0.262 * * * \\
(0.0643)\end{array}$ & $\begin{array}{c}0.268 * * * \\
(0.0705)\end{array}$ & $\begin{array}{c}0.329 \\
(0.199)\end{array}$ & $\begin{array}{c}0.394^{* *} \\
(0.191)\end{array}$ \\
\hline $\begin{array}{l}\text { Observations } \\
\text { R-squared }\end{array}$ & $\begin{array}{c}483 \\
0.008\end{array}$ & $\begin{array}{c}483 \\
0.008\end{array}$ & $\begin{array}{c}483 \\
0.013\end{array}$ & $\begin{array}{c}483 \\
0.035\end{array}$ \\
\hline
\end{tabular}

Notes: The dependent variable is the log of workforce in all sectors except "agriculture and related services”. Robust standard errors in parentheses, clustered at the Census Division level. *** $\mathrm{p}<0.01, * *$ $\mathrm{p}<0.05, * \mathrm{p}<0.1$ 
Table 6. Non-agricultural workforce, robustness to additional controls

\begin{tabular}{|c|c|c|c|}
\hline & \multicolumn{3}{|c|}{$\begin{array}{c}10 \text { year difference-in-differences }(2001-1991) \\
\text { Dependent variable: } \Delta \ln (\text { NonAG_Wkforce } \\
\text { i,2001-1991) }\end{array}$} \\
\hline & (1) & (2) & (3) \\
\hline$\Delta$ freight $_{i, 2001-1991}$ & $\begin{array}{c}-0.0266^{* * *} \\
(0.00761)\end{array}$ & $\begin{array}{c}-0.0271^{* * *} \\
(0.00684)\end{array}$ & $\begin{array}{l}-0.0273 * * * \\
(0.00695)\end{array}$ \\
\hline slocaldist $_{i, 2001-1991}$ & $\begin{array}{l}-0.00139 \\
(0.00138)\end{array}$ & $\begin{array}{l}1.99 \mathrm{e}-05 \\
(0.00117)\end{array}$ & $\begin{array}{l}-3.05 \mathrm{e}-05 \\
(0.00118)\end{array}$ \\
\hline precip $_{i}$ & $\begin{array}{c}0.000375 \\
(0.000239)\end{array}$ & $\begin{array}{l}-0.000157 \\
(0.000314)\end{array}$ & $\begin{array}{l}-0.000180 \\
(0.000308)\end{array}$ \\
\hline jan_temp ${ }_{i}$ & $\begin{array}{c}-0.0294 * * * \\
(0.00795)\end{array}$ & $\begin{array}{r}-0.00930 \\
(0.0111)\end{array}$ & $\begin{array}{l}-0.00887 \\
(0.0113)\end{array}$ \\
\hline july_temp $_{i}$ & $\begin{array}{c}0.0163 \\
(0.0156)\end{array}$ & $\begin{array}{c}0.0120 \\
(0.0188)\end{array}$ & $\begin{array}{c}0.0115 \\
(0.0190)\end{array}$ \\
\hline dist_urban $_{i}$ & $\begin{array}{c}-0.000834^{* *} \\
(0.000330)\end{array}$ & $\begin{array}{c}-0.000808^{* * *} \\
(0.000282)\end{array}$ & $\begin{array}{c}-0.000856^{* * *} \\
(0.000294)\end{array}$ \\
\hline$M B_{i}$ & $\begin{array}{l}-0.0715 \\
(0.0454)\end{array}$ & $\begin{array}{l}-0.0203 \\
(0.0426)\end{array}$ & $\begin{array}{l}-0.0156 \\
(0.0424)\end{array}$ \\
\hline$A B_{i}$ & $\begin{array}{c}0.0505 \\
(0.0576)\end{array}$ & $\begin{array}{l}-0.0435 \\
(0.0592)\end{array}$ & $\begin{array}{l}-0.0386 \\
(0.0611)\end{array}$ \\
\hline black $_{i}$ & & $\begin{array}{l}-0.000716 \\
(0.00127)\end{array}$ & $\begin{array}{l}-0.000718 \\
(0.00129)\end{array}$ \\
\hline darkgray $_{i}$ & & $\begin{array}{l}-0.000751 \\
(0.00132)\end{array}$ & $\begin{array}{r}-0.000713 \\
(0.00135)\end{array}$ \\
\hline gray $_{i}$ & & $\begin{array}{r}-0.000259 \\
(0.00140)\end{array}$ & $\begin{array}{l}-0.000276 \\
(0.00143)\end{array}$ \\
\hline darkbrown $_{i}$ & & $\begin{array}{r}-0.000908 \\
(0.00137)\end{array}$ & $\begin{array}{r}-0.000910 \\
(0.00139)\end{array}$ \\
\hline brown $_{i}$ & & $\begin{array}{l}-0.00282^{*} \\
(0.00156)\end{array}$ & $\begin{array}{l}-0.00285^{*} \\
(0.00157)\end{array}$ \\
\hline educ $c_{i}$ & & & $\begin{array}{l}-0.477 \\
(0.725)\end{array}$ \\
\hline Constant & $\begin{array}{c}-0.190 \\
(0.372)\end{array}$ & $\begin{array}{c}0.542 \\
(0.454)\end{array}$ & $\begin{array}{c}0.592 \\
(0.460)\end{array}$ \\
\hline Observations & 484 & 461 & 461 \\
\hline R-squared & 0.141 & 0.185 & 0.187 \\
\hline
\end{tabular}

Notes: The dependent variable is the log of workforce in all sectors except "agriculture and related services”. Robust standard errors in parentheses, clustered at the Census Division level. ${ }^{* * *} \mathrm{p}<0.01$, ** $\mathrm{p}<0.05, * \mathrm{p}<0.1$ 


\section{Appendix}
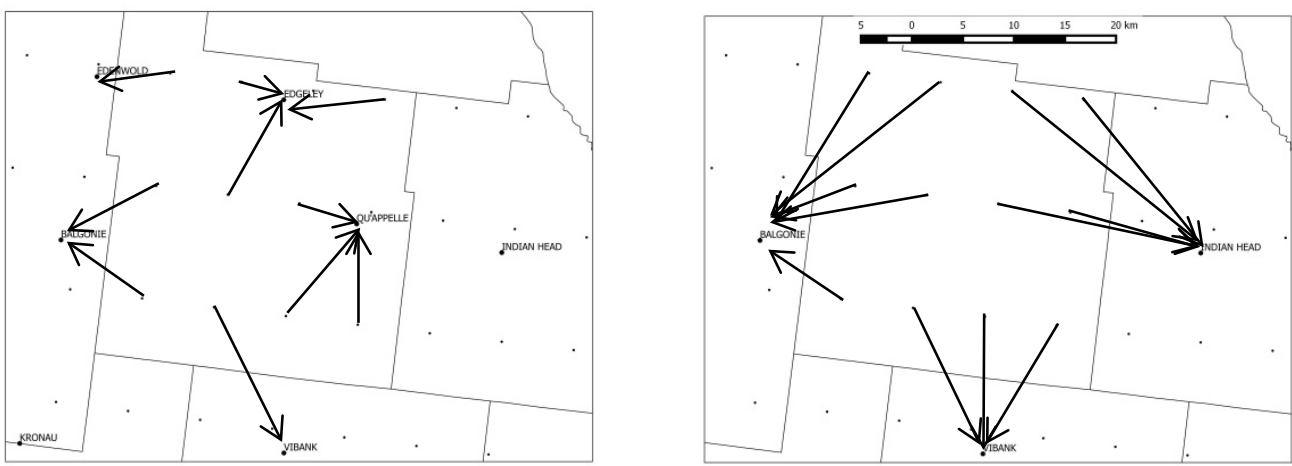

Figure A1. Measurement of local trucking distances in 1991 (left panel) and 2001 (right panel), South Qu’Appelle No. 157. Source: Statistics Canada and Freight Rate Manager.

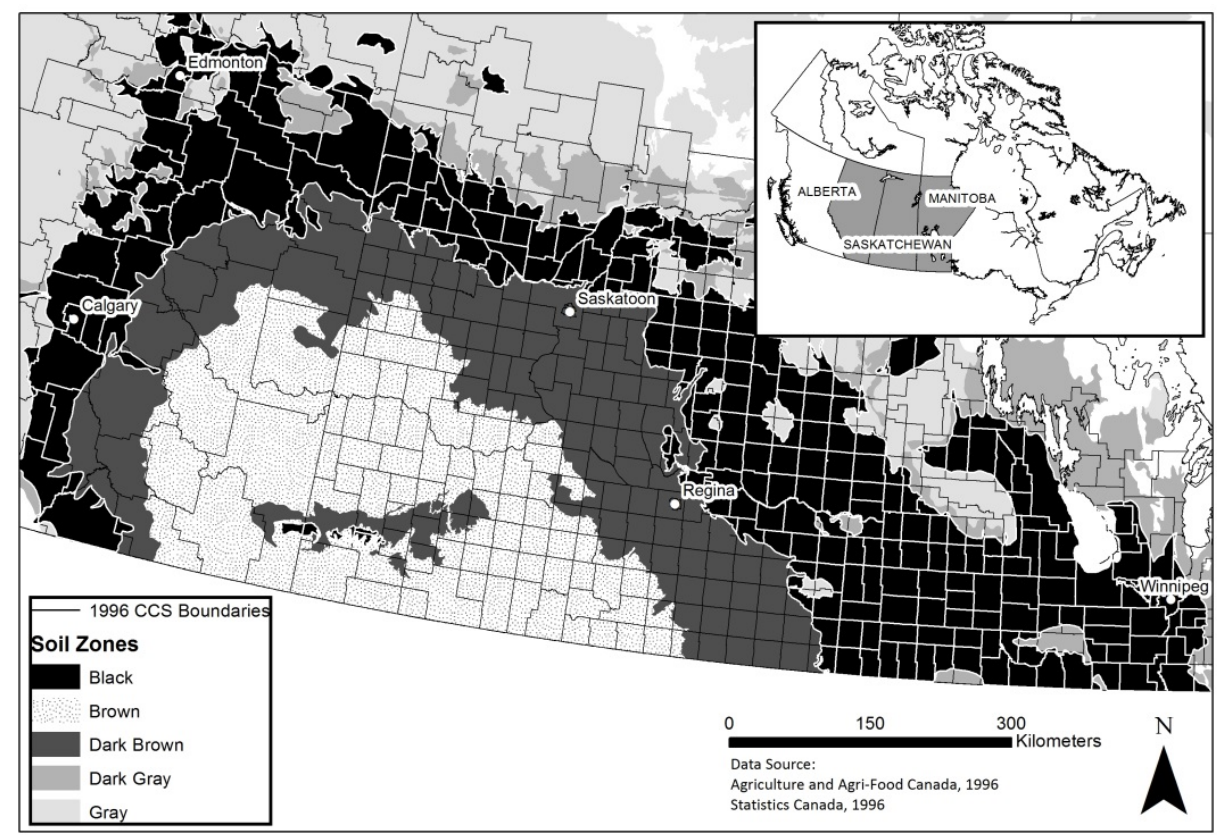

Figure A2. Soil Zones and 1996 Census Consolidated Subdivision Boundaries for the Prairie Provinces 
Table A1. Weighted regressions

\begin{tabular}{|c|c|c|c|c|}
\hline \multirow[b]{2}{*}{ Dep. Var.: } & \multicolumn{4}{|c|}{10 year first-difference (2001-1991) } \\
\hline & $\begin{array}{l}\Delta \ln \left(\text { revenue }_{i, 01-91}\right) \\
\text { (1) }\end{array}$ & $\begin{array}{l}\Delta \operatorname{sln}\left(\text { valuelb }_{i, 01-91}\right) \\
\text { (2) }\end{array}$ & $\begin{array}{l}\Delta \ln \left(\text { numfarm }_{i, 01-91}\right) \\
\text { (3) }\end{array}$ & $\begin{array}{c}\Delta \ln (\text { nonAG } \\
\text { (4) }\end{array}$ \\
\hline$\Delta$ freight $_{i, 2001-1991}$ & $\begin{array}{c}-0.0131^{* *} \\
(0.00631)\end{array}$ & $\begin{array}{c}-0.0297 * * * \\
(0.00555)\end{array}$ & $\begin{array}{c}-0.00835^{* * *} \\
(0.00242)\end{array}$ & $\begin{array}{c}-0.0142 * * * \\
(0.00486)\end{array}$ \\
\hline Slocaldist $_{i, 2001-1991}$ & $\begin{array}{c}0.00175 \\
(0.00116)\end{array}$ & $\begin{array}{l}0.000675 \\
(0.00109)\end{array}$ & $\begin{array}{l}0.00244^{* *} \\
(0.000975)\end{array}$ & $\begin{array}{l}-0.00156 \\
(0.00108)\end{array}$ \\
\hline precip $_{i}$ & $\begin{array}{c}9.72 \mathrm{e}-05 \\
(0.000238)\end{array}$ & $\begin{array}{c}0.000391 * * \\
(0.000169)\end{array}$ & $\begin{array}{l}-2.39 \mathrm{e}-05 \\
(8.27 \mathrm{e}-05)\end{array}$ & $\begin{array}{l}-0.000193 \\
(0.000189)\end{array}$ \\
\hline jan_temp $_{i}$ & $\begin{array}{c}0.0140^{*} \\
(0.00746)\end{array}$ & $\begin{array}{l}0.0133^{* *} \\
(0.00540)\end{array}$ & $\begin{array}{c}0.00328 \\
(0.00305)\end{array}$ & $\begin{array}{c}-0.00624 \\
(0.00416)\end{array}$ \\
\hline july_temp $i$ & $\begin{array}{c}0.0137 \\
(0.0124)\end{array}$ & $\begin{array}{c}-0.0137 \\
(0.0106)\end{array}$ & $\begin{array}{c}-0.0212 * * * \\
(0.00588)\end{array}$ & $\begin{array}{c}-0.0391 * * * \\
(0.0136)\end{array}$ \\
\hline dist_urban $_{i}$ & $\begin{array}{l}-0.000143 \\
(0.000319)\end{array}$ & $\begin{array}{c}0.000189 \\
(0.000295)\end{array}$ & $\begin{array}{l}-0.000302 \\
(0.000202)\end{array}$ & $\begin{array}{c}0.000133 \\
(0.000215)\end{array}$ \\
\hline Constant & $\begin{array}{l}0.430^{*} \\
(0.243)\end{array}$ & $\begin{array}{c}1.057 * * * \\
(0.189)\end{array}$ & $\begin{array}{c}0.467 * * * \\
(0.122)\end{array}$ & $\begin{array}{c}1.074 * * * \\
(0.177)\end{array}$ \\
\hline Observations & 473 & 473 & 474 & 484 \\
\hline R-squared & 0.087 & 0.383 & 0.206 & 0.395 \\
\hline Weighting Var.: & revenue $_{i, 1991}$ & valuelb $_{i, 1991}$ & numfarm $_{i, 1991}$ & tot_pop ${ }_{i, 1991}$ \\
\hline
\end{tabular}

Notes: Robust standard errors in parentheses, clustered at the Census Division level. ${ }^{* * *} \mathrm{p}<0.01,{ }^{* *}$ $\mathrm{p}<0.05,{ }^{*} \mathrm{p}<0.1$ 
Table A2. Robustness to excluding "predominantly urban" CCS's

\begin{tabular}{|c|c|c|c|c|}
\hline \multirow[b]{2}{*}{ Dep. Var.: } & \multicolumn{4}{|c|}{10 year first-difference (2001-1991) } \\
\hline & $\begin{array}{l}\Delta \ln \left(\text { revenue }_{i, 01-91}\right) \\
\text { (1) }\end{array}$ & $\begin{array}{l}\Delta \ln \left(\text { valuelb }_{i, 01-91}\right) \\
\text { (2) }\end{array}$ & $\begin{array}{l}\Delta \ln \left(\text { numfarm }_{i, 01-91}\right) \\
\text { (3) }\end{array}$ & $\begin{array}{c}\Delta \ln \left(\text { nonAG }_{i, 01-91}\right) \\
\text { (4) }\end{array}$ \\
\hline$\Delta$ freight $_{i, 2001-1991}$ & $\begin{array}{l}-0.0112 * \\
(0.00621)\end{array}$ & $\begin{array}{c}-0.0300 * * * \\
(0.00570)\end{array}$ & $\begin{array}{c}-0.00729 * * * \\
(0.00238)\end{array}$ & $\begin{array}{c}-0.0252 * * * \\
(0.00676)\end{array}$ \\
\hline slocaldist $_{i, 2001-1991}$ & $\begin{array}{l}0.00198 * \\
(0.00107)\end{array}$ & $\begin{array}{c}0.00118 \\
(0.00101)\end{array}$ & $\begin{array}{c}0.00276^{* * *} \\
(0.000927)\end{array}$ & $\begin{array}{l}-0.00113 \\
(0.00141)\end{array}$ \\
\hline precip $_{i}$ & $\begin{array}{c}7.66 \mathrm{e}-05 \\
(0.000251)\end{array}$ & $\begin{array}{c}0.000363 * * \\
(0.000180)\end{array}$ & $\begin{array}{l}-4.32 \mathrm{e}-05 \\
(9.00 \mathrm{e}-05)\end{array}$ & $\begin{array}{c}0.000135 \\
(0.000159)\end{array}$ \\
\hline jan_temp $_{i}$ & $\begin{array}{c}0.0121^{*} \\
(0.00670)\end{array}$ & $\begin{array}{l}0.00964^{*} \\
(0.00520)\end{array}$ & $\begin{array}{c}0.00142 \\
(0.00268)\end{array}$ & $\begin{array}{c}-0.0262 * * * \\
(0.00698)\end{array}$ \\
\hline july_temp $_{i}$ & $\begin{array}{c}0.0128 \\
(0.0120)\end{array}$ & $\begin{array}{l}-0.00789 \\
(0.0105)\end{array}$ & $\begin{array}{c}-0.0183 * * * \\
(0.00611)\end{array}$ & $\begin{array}{l}0.00437 \\
(0.0110)\end{array}$ \\
\hline dist_urban $_{i}$ & $\begin{array}{c}-2.92 \mathrm{e}-05 \\
(0.000301)\end{array}$ & $\begin{array}{c}0.000214 \\
(0.000298)\end{array}$ & $\begin{array}{l}-0.000218 \\
(0.000209)\end{array}$ & $\begin{array}{c}-0.000832 * * \\
(0.000342)\end{array}$ \\
\hline Constant & $\begin{array}{l}0.370^{*} \\
(0.207)\end{array}$ & $\begin{array}{c}0.906^{* * *} \\
(0.161)\end{array}$ & $\begin{array}{c}0.360 * * * \\
(0.102)\end{array}$ & $\begin{array}{c}0.133 \\
(0.195)\end{array}$ \\
\hline Observations & 461 & 461 & 462 & 471 \\
\hline R-squared & 0.069 & 0.321 & 0.153 & 0.125 \\
\hline
\end{tabular}

Notes: Robust standard errors in parentheses, clustered at the Census Division level. $* * * \mathrm{p}<0.01, * *$ $\mathrm{p}<0.05, * \mathrm{p}<0.1$ 
${ }^{1}$ This study also contributes to growing literature studying the impacts of trade liberalization on local labor markets, such as Autor et al. (2013), who study the impact of Chinese imports on U.S. regions.

${ }^{2}$ Partridge et al. (2008) also find that distance to urban centers is an important driver of population growth in the U.S.

${ }^{3}$ The announcement came in February of 1995 to be effective August 1995 (Doan, Paddock and Dyer 2003). This was the culmination of decades of threats to repeal the subsidy, all of which may have led to expectations of its removal. However, since it was under discussion for so long, it would have been hard to anticipate the actual timing of the repeal, which had as much to do with federal government deficits as with the grain industry. Further, though there were reforms in the 1983 Western Grain Transportation Act, this Act institutionalized the payment of a 'Crow Benefit' to the railways, keeping farm rates low (Klein et al. 1994), thus giving farmers confidence that farm-level transportation cost increases may be avoided.

${ }^{4}$ See Vercammen (1996a) for a detailed overview of reforms to the Western Canadian grain transportation system.

${ }^{5}$ This assumes an average grain price of \$200/tonne.

${ }^{6}$ Ross (2006) indicates that major changes in elevator design began as early as the late 1970's when increased capacity handling facilities began to appear, but in the 1990s most grain companies constructed high capacity, high throughput terminals with 50,000 tonnes storage, allowing for an entire train of 53 cars to be loaded in a single day.

${ }^{7}$ The Uruguay Round's Agriculture Agreement stipulated that export subsidies were to be reduced by 36 percent of what was spent in 1991/92 by the year 2000 . 
Moreover, this reduction was to apply to at least 21 percent of the volume shipped in 1991/92 (Kraft and Doiron 2000).

8 The re-location of the eastern export basis point discouraged the export of wheat and barley to ports in eastern Canada. However, west coast capacity constraints led to an additional measure, the freight rate adjustment factor (FAF), which had the effect of re-establishing freight rates consistent with a Thunder Bay export basis point, for eastward movement of wheat and barley. Financed by all producers across the prairies, the FAF largely averted the additional impact of moving the eastern basis point to the St. Lawrence (Fulton et al. 1998). Freight rates for wheat, adjusted for west coast capacity constraints, can thus be interpreted as an "export basis.”

${ }^{9}$ An additional and important part of the context was the grain transportation deregulation and innovations that had been underway in the U.S. Midwest for at least two decades prior to WGTA repeal in Canada. Major efficiency gains had been won through the adoption of covered hopper cars, multi-car shipments, shuttle cars, forward shipping instruments and short line rail lines (Wilson 2000, 2011). These ongoing changes both underlined potential efficiency improvements in grain handling and transportation for Canada, and the potential for increased grain flows through and to U.S. destinations from prairie origins, in the absence of the WGTA and CWB in Canada (Wilson 1995).

${ }^{10}$ In retrospect, the access to efficient slaughter plants became a more important factor after 2006 (Bell 2006) and this constrained the growth of hog production in CCSs with a larger increase in freight rates because these CCSs were also more distant from the efficient hog slaughtering facilities.

${ }^{11}$ In the case of the U.S., the USDA (2014) found that every $\$ 1$ billion of U.S. agricultural exports in 2014 required approximately 7500 American jobs 
throughout the economy, with approximately $60 \%$ of those jobs accruing to the non-farm sector.

${ }^{12}$ Ferguson and Olfert (2016) use the same empirical strategy to evaluate the impact of the WGTA reform on technology adoption and land use at the CCS level of aggregation.

${ }^{13}$ Davey and Furtan (2008) find that soil zone and growing season weather averages explained regional differences in conservation tillage adoption levels in using a pooled sample of farm-level data for 1991, 1996 and 2001.

${ }^{14}$ The "experienced workforce" includes everyone with a job during the week of the census (in mid-May) plus, for those unemployed, it includes those who held a job at one time since January $1^{\text {st }}$ of the previous year. It includes all selfemployed, paid and unpaid family workers.

${ }^{15}$ This service provides farmers with information on the cost of shipping various crops by rail, depending on their location. See http://freightratemanager.usask.ca/index.html for more details on the source of the freight rate data.

${ }^{16}$ Using shipment volume data from the Canadian Grain Commission (2014) for each station, we exclude stations that report total train deliveries per year of $1000 \mathrm{mt}$ or less.

${ }^{17}$ We restrict the grid points to only those where crops are actually grown, using satellite data from Ramankutty et al. (2008). Grid points are excluded if less than $10 \%$ of the surrounding land is devoted to crops or pasture. The average number of grid points in a CCS is 17, and the median number of grid points in a CCS is 12. See figure A1 in the Appendix for an example of how grid points are matched to delivery locations. 
${ }^{18}$ Figure A1 in the Appendix illustrates how local trucking distance increased between 1991 and 2001 for one particular CCS (South Qu’Appelle No. 157). The average local trucking distance increased from $8.4 \mathrm{~km}$ to $16.8 \mathrm{~km}$.

${ }^{19}$ Handling charges and freight rates for canola and other grains evolved similarly to those for wheat, (SAFRR 2003, Tables 2-43 and 2-44).

${ }^{20}$ It is important to note that gross farm revenue reported to the Census of Agriculture is net of freight rates (charged by railway companies) and net of elevation and storage fees (charged by elevator companies).

${ }^{21}$ Median non-agricultural employment per CCS is 522 persons, thus a $2.46 \%$ decrease in non-agricultural employment corresponds to decrease in employment of 12.84 persons.

${ }^{22}$ The impact of a one dollar freight rate increase on farm revenues assumes an average crop yield of one tonne per acre and uses the median number of 124,000 acres in crops per CCS.

${ }^{23}$ We follow Hornbeck's (2012) weighting strategy using pre-treatment population, farm revenues and land values when analyzing the impact of the American dust bowl on employment, farm revenues and land values at the county level. 